\title{
Vertical Farming: An Assessment of Singapore City
}

\author{
Jacob Wood \\ https://orcid.org/0000-0002-3096-5159
}

James Cook University Singapore \& Chungnam National University, South Korea

Caroline Wong

https://orcid.org/0000-0002-0860-0540

James Cook University Singapore

Swathi Paturi

James Cook University Singapore

\begin{abstract}
Urban planners, government leaders, and the farming community have noted the important role cities play in producing their own food to manage higher levels of domestic demand, food insecurity, environmental concerns and affordability. To better understand these issues our research examines urban farming; in particular, the use of vertical farming methods. Such approaches can be used to overcome not only food safety and land resource issues, but also better manage the threats posed by rapid urbanisation. With technological developments in hydroponics, aeroponics and aquaponics, vertical farming has become a much more efficient and affordable means of farming in urban spaces. Overall, these high-tech systems signify a shift in the ways farming and food production can be operationalised. The results from our analysis show that Singapore, a tropical city in Asia, is making significant strides in vertical farming with substantial public and private investment in R\&D through high-tech, high-yielding, land-limited farms in high-rise buildings. Despite these initiatives, Singapore faces a highly constrained urban environment where land scarcity is exacerbated by a complex regulatory land use framework.
\end{abstract}

Keywords: Singapore, vertical farming, urbanisation, cities, food security, urban farming

eTropic: electronic journal of studies in the tropics publishes new research from arts, humanities, social sciences and allied fields on the variety and interrelatedness of nature, culture, and society in the tropics. Published by James Cook University, a leading research institution on critical issues facing the worlds' Tropics. Free open access, Scopus Listed, Scimago Q2. Indexed in: Google Scholar, DOAJ, Crossref, Ulrich's, SHERPA/RoMEO, Pandora. ISSN 1448-2940. Creative Commons CC BY 4.0 free to download, save and reproduce. To cite, include: Author(s), Title, eTropic, volume, issue, year, pages and DOI: http://dx.doi.org/10.25120/etropic.19.2.2020.3745 
eTropic 19.2 (2020) Special Issue: Sustainable Tropical Urbanism

\section{Introduction}

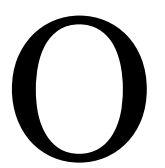

ver the next 50 years rapidly evolving climate change issues will play a major role in developing the state of global agriculture. It is estimated that a 1degree increase in atmospheric temperature will lead to a 10 percent decrease in the amount of land suitable for agricultural purposes (Despommier, 2011). Parallel to climate change factors is the significant rate of urbanisaton, with some 55 percent of the world's population currently living in urban areas; a proportion that is expected to increase to 68 percent by 2050 (United Nations, 2018). Furthermore, changes in lifestyle, food consumption patterns and source of livelihoods are all threatening food security (FAO, 2017). Given such developments there is a strong need to adopt more innovative approaches to achieving higher levels of food security in urban settings, and urban farming is one such technique (Poulsen et al., 2015; Siegner et al., 2018; Smit \& Nasr, 1992).

Urban farming has become an important global trend in recent decades (Yuan et al., 2019). Its growing appeal reflects not only attempts to overcome food safety and land resource issues, but also a growing need to provide sustainable living environments that manage the threats posed by rapid urbanisaton (Shamshiri et al., 2018). Defined as "growing and raising food crops and animals in an urban setting for the purpose of feeding local populations" (Pfeiffer et al., 2013, p. 79), urban farming has become an important feature of modern agriculture. It is now well-recognised by leading international organisations, such as the Food and Agriculture Organization (FAO) and UN-Habitat (FAO, 2014; UN-Habitat, 2014), despite the fact that people living in cities have at times tended to criticise innovative forms of urban agriculture (Benis \& Ferrao, 2018; Sanye-Mengual, et al., 2016). A key innovation in urban farming has been the development of vertical farming methods. Vertical farming, which involves the process of growing plants in a vertically layered system, is one of the most common types of urban farming systems, particularly in densely populated cities like Singapore which has limited land resources at its disposal. With the assistance of technological developments in vertical farming like hydroponics, aeroponics, and aquaponics, this form of farming has become an efficient and increasingly affordable means of using urban spaces for agricultural production.

Singapore, as both a densely populated city and a major net food-importer, provides a perfect location for vertical farming. At present, the country imports more than $90 \%$ of all the food it consumes and has less than $1 \%$ of its total land available for food production (SFA, 2020). In addition, more than $80 \%$ of Singapore's population lives in public housing areas known as Housing and Development Board (HDB) apartments 
eTropic 19.2 (2020) Special Issue: Sustainable Tropical Urbanism

(Astee \& Kishnani, 2010). ${ }^{1}$ The extensive scale of these housing estates with their rooftop spaces represents a significant opportunity for the implementation of largescale agricultural operations within the urban landscape. These HDB estates are well supported by infrastructure development and public utility services ranging from common spaces, carparks, and waste collection, to block maintenance. Given this context, this research seeks to understand how Singapore embraces vertical farming opportunities by exploring the following research questions:

- How does Singapore adopt and practice urban farming?

- To what extent do government policy initiatives support urban farming?

- What are some of the challenges encountered in urban farming and how feasible is it for Singapore's urban farming model to be adopted by other cities?

This urban farming study differs from earlier works in several ways. Firstly, it provides a detailed assessment of the literature surrounding vertical farming, the benefits and challenges, as well as the important role technology plays in the industry. Secondly, its specific Singapore focus provides a comprehensive assessment of the policy initiatives being implemented to support urban farming in the country. Finally, it highlights the challenges facing the industry and provides insights into how Singapore's urban farming model can be adopted or tailored to suit the needs of other tropical cities.

\section{Literature Review}

\section{Positives of Vertical Urban Farming}

Driven by global imperatives such as climate change mitigation, more equitable economic models, and health concerns, urban agriculture has moved from an issue at the edge of public discourse to one very much at its centre (Bohn \& Viljoen, 2011). Relevant academic discussions on urban farming often encompass three pillars. They include: improving urban food security, reducing emissions due to food items travelling shorter distances (food miles), and enhancing economic opportunities for the local economy.

Assessment of the literature highlights a series of advantages and relevant challenges of conducting urban farming. The main advantages of urban agriculture are that the farming, marketing, and consumption can be carried out predominantly within urban precincts. This negates the need for produce to be brought in from rural areas or from overseas (Subramanian \& Lee, 2012). Urban agriculture also promotes employment

\footnotetext{
${ }^{1}$ For an understanding of the significance, both historical and contemporary, of HDB apartments please refer to the extensive overview provided by Kuah (2018).
} 
opportunities, especially for the urban poor and rural migrants (Smit et al., 2001). Although urban poverty is not prevalent in Singapore, social researchers have estimated that $10-15 \%$ of Singaporean households fall within the low-income bracket (Leyl, 2014). Moreover, studies have reported a myriad of other benefits associated with urban farming, such as increased fruit and vegetable consumption and exercise (Mansfield \& Mendes, 2013; Taylor \& Lovell, 2012), increased social wellbeing, a sense of community coherence, and political engagement (Armstrong, 2000; Hale et al., 2011; Morgan, 2015). In addition, other studies have highlighted ecological benefits through the greening of urban environments, decreasing urban heat-island effects and providing wastewater diversion (Chen \& Wong, 2005; Grewal \& Grewal, 2012; Haberman et al., 2014; Johnson et al., 2015). Combating climate change and adopting sustainable methods of agriculture are also important motivations for urban farming (Poulsen et al., 2015).

Urban farming represents a desire to move away from traditional commercial farming methods which are more resource intensive and have a larger carbon footprint (Yuttitham, 2019). Vertical farms are also able to grow a variety of products at any given time throughout the year (Platt, 2007; Sivamani et al., 2014) and are able to produce far greater quantities of food per square meter than traditional forms of farming (Kalantari et al., 2018). Moreover, the food itself does not need to travel vast distances in order to be consumed. As Van der Schans and Wiskerke (2012) note, short urban agriculture food supply chains enable the provision of high-quality niche products such as perishable vegetables that may be sold at premium prices (Hinrichs, 2000). Despite these benefits, Despommier (2010) argues that vertical farming is not a panacea for all existing sustainability problems, however, it can contribute significantly to sustainable production by moving agriculture in the direction of agroecology.

From an economic perspective, urban farming also has a positive impact on job creation (Surls et al., 2015), encouraging the engagement of youth and volunteer workers and the provision of skill development for job training programs (Pfeiffer et al., 2013). It additionally helps to overcome the phenomenon of 'food-desserts' in urban areas, which are characterised by the existence of fewer grocery stores and more fast food restaurants in low income neighbourhoods (Segal, 2010; Opitz et al., 2016). Given such a context, and issues surrounding the urban poor, the practice of growing food within cities for local consumption has been widely advocated as a practical solution for Singapore.

The rise of vertical farming technologies has been instrumental in securing food for urban dwellers. A key factor in this regard is its efficiency with Despommier (2010) arguing that vertical farming is more efficient than traditional farming methods because 
eTropic 19.2 (2020) Special Issue: Sustainable Tropical Urbanism

it has the capability to grow fresh produce all year round, increase total yield opportunities, and simultaneously decrease food waste across the supply chain. It also has the ability to improve food security (Fatemah et al., 2018) and attract significant new investment opportunities - with some \$414 million USD invested in 2017/18 (Toledano, 2019). Benke and Tonkins (2017) noted that vertically farmed produce has a clear competitive advantage in its so-called 'CGG' (clean, green and gourmet) appeal. A good example of this is AeroFarms based out of New York, which uses aeroponic technology to grow produce such as kale, berries and watercress. Recently AeroFarms collaborated with Singapore Airlines to provide the air service with fresh leafy greens (Fortado \& Terazono, 2019).

\section{Challenges Associated with Vertical Urban Farming}

Despite its benefits, there is a wide array of research that highlights the challenges of vertical farming in urban settings. A key critique surrounds energy use, more specifically, how plants growing inside a building will receive the energy they need for plant growth (Al-Chalabi, 2015; Specht et al., 2014). Such costs do much to undermine the sustainability gains that form a key benefit of urban farming (The Economist, 2010). Normal vertical farming systems use both natural and artificial light forms as their main energy source. Energy intensive forms of artificial lighting are crucial for photosynthesis and photoperiodic (time and duration) as well as the structure (dimensional light dissemination) of plants (Germer et al., 2011). Because they are situated in buildings where access to natural light is low, there is a strong need for LED lighting which creates additional overhead costings that must be taken into consideration (Banerjee \& Adenaeuer, 2014). According to calculations by Perez (2014), if the United States agricultural industry adopted a vertical approach the electricity required to supply lighting to the ventures would be $800 \%$ greater than the total electricity currently generated in the country.

Another challenge closely related to lighting is the level of heat by-product that is produced. This could be of particular concern in summer when it may interfere with air conditioning systems in a building (Kalantari et al., 2018). Likewise, the need to create a humid environment that maximises plant growth incurs additional costs for growers, as does the building of the vertical towers themselves (Ellingsen \& Despommier, 2008).

Concerns surrounding demand for water in vertical farming are also well documented within the literature (Kalantari et al., 2018). A critical factor behind the success of a vertical farm is its water supply (Perez, 2014). The best and most efficient means of water consumption is facilitated through aeroponics and hydroponics. Not only can these approaches help save up to $95 \%$ of total water used (Kalantari et al., 2018), they 
eTropic 19.2 (2020) Special Issue: Sustainable Tropical Urbanism

can also help to remove wastewater which is potentially hazardous to the environment and human health (Voss, 2013). However, these technologies are expensive to set up and require significant expertise in terms of their monitoring and upkeep. These costs then lead to other economic challenges, which are at a particular disadvantage when compared with traditional farming methods (Banerjee \& Adenaeuer, 2014)

Pollution is identified as another problem. Urban farming has a negative impact on soil, air and water quality. In general, fruit and vegetables produced in city environments contain more undesirable substances than rural produce. City air has elevated levels of nitrogen oxides, sulphur oxides, hydrocarbons and particulates from car exhausts (Meharg, 2016). Air pollution is known to reduce urban crop yields, while inorganic fertilizers and manures pollute water supplies, which leads to excessive build-up of algae and aquatic plants in nutrient-rich waters (Meharg, 2016). Agricultural run-off is one of the major sources of contamination in the world today (Ellis, 2012). Many cities struggle to supply water for domestic and industrial use and hence largescale hydroponic farms would be a further burden on a precious resource.

Finally, the literature notes that vertical farming does not contribute to food security in any meaningful way, nor does it improve the affordability of food (Badami \& Ramankutty, 2015). Other studies by Boisvert (2013) question the relative efficacy of using densely populated urban environments that have little real space for agriculture, particularly if these spaces could support other more productive industrial and economic development objectives.

\section{Important Technological Considerations}

A key pioneering technology that has helped to facilitate the widespread adoption of urban farming has been vertical farming. In theory, vertical farming is an agricultural technique involving large-scale food production in high-rise buildings. This enables fast growth and planned production by controlling environmental conditions and nutrient solutions to crops through the use of hydroponics and cutting-edge greenhouse methods (Abel, 2010; Banerjee \& Adenaeuer, 2014; Despommier, 2010, 2011).

There are primarily three technologies used in vertical farming. These are hydroponics, aeroponics and aquaponics (see Table 1). Urban farms use these technologies, or hybrid forms of these technologies, in order to produce food. 
eTropic 19.2 (2020) Special Issue: Sustainable Tropical Urbanism

Table 1 Technologies used in urban farming

\begin{tabular}{|l|l|}
\hline Type/Technology & Farming Example \\
\hline Hydroponics & $\begin{array}{l}\text { Oh Chin Huat Hydroponic Farms: Singapore } \\
\text { ertiCorp TM: Vancouver, Canada } \\
\text { Nuvege Plant Factory: Kyoto, Japan }\end{array}$ \\
\hline Aeroponics & $\begin{array}{l}\text { AeroFarms: USA } \\
\text { Planned Vertical Farm: Linkoping, Sweden } \\
\text { Ky Greens Farms: Singapore }\end{array}$ \\
\hline Aquaponics & $\begin{array}{l}\text { Ecoponics: Iceland } \\
\text { The Plant Vertical Farm: Chicago, USA }\end{array}$ \\
\hline $\begin{array}{l}\text { Greenhouses } \\
\text { Controlled Environment Agriculture }\end{array}$ & $\begin{array}{l}\text { Green Sense Farms: Indiana USA \& Shenzhen, China } \\
\text { eroFarms: Newark, New Jersey }\end{array}$ \\
\hline
\end{tabular}

Sources: Kalantari et al., (2017) and Kalantari et al., (2018).

A key innovation used in vertical farming is aquaponics, an approach that combines aquaculture and hydroculture (Specht et al., 2019). Such a technique allows for the production of both fish and leafy vegetables in urban environments (Love et al., 2015) in a manner that is much more efficient than aquaculture alone as both the nutrients and water are recycled (Cohen et al., 2018). In contrast, Forchino et al., (2018) concluded from their lifecycle study that high demand for energy and water are key obstacles for achieving economic and environmental sustainability in urban farming projects. Operational costs and concerns over increased fertiliser use and the need for constant technological development also negatively affect sustainability (SanjuanDelmás et al., 2018). However, if appropriate design measures are taken vertical farming through roof top greenhouses can be an efficient way of producing food (Specht et al., 2019). These types of enterprises can utilise the often unused space at the top of HDB buildings in Singapore in a way that creates a synergetic relationship with the building (Benis et al., 2018). Moreover, these high-tech facilities can use waste heat from the building to warm the greenhouse, while the $\mathrm{CO}_{2}$ emissions can be used to encourage plant growth (Montero et al., 2017). Moreover, because these urban farms are situated on rooftops a large proportion of the water demand can be supplied by collecting rainwater (Sanjuan-Delmás et al., 2018).

While rooftop farming is a key approach, indoor farming can also provide optimal growing conditions that maximise potential yields (Specht et al., 2019) and enable year-round production in cities with more temperate climates (Despommier, 2013). As 
eTropic 19.2 (2020) Special Issue: Sustainable Tropical Urbanism

is the case with vertical farming, soil-less vertical plant-production systems are preferred in indoor environments (Sanjuan-Delmás et al., 2018). It is also important to note that control over production methods can reduce the need for fertilisers and pesticides, which in turn can reduce the level of environment impact during the food production process (Specht et al., 2014).

While these approaches are the most common forms of urban farming, there are also new innovative concepts such as insect or algae farming which are growing in appeal. In terms of traditional farming approaches, insect farming is regarded as being more environmentally friendly and less resource-intensive (Specht et al., 2019) Moreover, the water demand and space requirements for insect farming are much less (Van Huis, 2013). Furthermore, edible insects like mealworms or grasshoppers emit very low greenhouse gas levels (Oonincx et al., 2010). Likewise, algae farming has several important benefits over growing vegetables. These include the need for less fertilizer and the speed at which algae grows and can be harvested (Specht et al., 2019). Algae farms can conveniently be placed vertically on both house facades and the interior walls of buildings. Despite their appeal, the implementation of each of these approaches on a large-scale is very expensive and technologically challenging (Draaisma et al., 2013).

Despite the important role that technology can play in driving change across the urban farming landscape, assessing the technical feasibility is a common barrier that often hinders these developments from going beyond their prototype phases (Specht et al., 2016). This is a key reason why an analysis of the long-term sustainability of new approaches in urban agriculture can only be assessed from a model-based perspective (Banerjee \& Adenaeuer, 2014; Al-Chalabi, 2015). Meanwhile, research into aquaponics, vertical farming, rooftop greenhouses, and indoor farming, emphasises the technological feasibility and production-process optimisation techniques that can be used (Benis et al., 2018; Sanyé-Mengual et al., 2016).

\section{Discussion}

Since Singapore gained the highest ranking in the Global Food Security Index - which measures food affordability, people's physical access to food, and the safety and nutrition levels of the available food - in 2018 and 2019 (The Economist EIU, 2019), the country has demonstrated its ability to provide a diverse supply of food, $90 \%$ of which is imported from other countries. However, when taking into account climaterelated and natural resource risk factors, import-reliant Singapore falls to 12th place on the index (Liu, 2019, December 10). For example, the COVID-19 pandemic of 2020, has exposed Singapore's vulnerability to external shocks that affect global food supply and, in turn, Singapore's food security. In order to make its diversified import 
eTropic 19.2 (2020) Special Issue: Sustainable Tropical Urbanism

strategy more robust, Singapore is planning to complement its current import reliance by increasing local production to $30 \%$ of the country's nutritional needs by 2030 , as part of the "30 by 30" goal that was set in 2019 (Liu, 2019, December 10).

Through substantial investment in research and development (R\&D) Singapore is aiming to grow its food supply through high-tech, high-producing, land-limited farms. Public and private investment in the R\&D of high tech food production comes by way of "hydroponics, aquaponics, vertical and rooftop farming" (Diehl et al., 2019, p.47). Therefore, Singapore is striving to develop innovative, climate-resilient technologies that increase its local production in a sustainable way. Given the current COVID-19 pandemic situation, this has meant even greater impetus has been given to the development of vertical farming solutions. Amid the crisis, Singapore has launched a new SGD $\$ 30$ million grant, known as the "30x30", which invests in local urban farms increasing their production capabilities (Liu, 2020, April 8).

\section{Development of Urban Farming in Singapore}

Prior to the significant up-take in vertical farming ventures in Singapore, the Singapore National Parks initiated the popular "Community in Bloom" programme - a nationwide gardening initiative which started in 2005 and today has more than 1,500 community gardens across Singapore (Singapore National Parks, n.d.). About $80 \%$ of the community gardens featuring edible greens are located within the surrounds of public HDB flats (Zachariah, 2017).

Given such encouragement, the "citizen farm" - a sustainable and socially driven community farm which commercialises its products and provides training and educational content (Low, 2019), has sprung up in recent years. For example, a private enterprise called Edible Garden City that specialises in building urban gardens and providing consultancy to community farming initiatives was launched with the help of government support in 2012 (Low, 2019). Since its establishment, it has built more than 200 edible gardens and transformed a former golf course into a permaculture community garden which grows 50 varieties of vegetables and herbs, tropical fruit trees and raises chickens, which are used in the Open Farm Community restaurant's high-quality, organic dishes (Low, 2019). The organisation has its own urban farm called Citizen Farm in which it grows, packs, and sells products directly to the market at a competitive price (Low, 2019). Other rooftop-farming enterprises, such as Citiponics Farm @ Ang Mo Kio, have also proven to be highly successful from a socioeconomic perspective by providing employment to elderly residents in the nearby HDB blocks (Teh, 2019). Meanwhile, Orchidville farm in Choa Chu Kang Road grows 8000 lettuce heads and, at the same time, rears 8000 tilapia fish (Boh, 2017). 
eTropic 19.2 (2020) Special Issue: Sustainable Tropical Urbanism

On the community front, Singapore's public housing environment provides the perfect platform from which local food production can be increased. A Singapore-based study by Astee and Kishnani (2010) demonstrated that if the rooftops of public HDB housing areas are used for food production local production can be increased to $35.5 \%$ from current $5.5 \%$ levels, while at the same time reducing carbon emissions and enhancing new biofuel production opportunities. In a recent attempt to stimulate its "30 by 30 " food production goal, the government investigated converting nine multi-storey carpark rooftops in public housing areas into urban farms to be leased out to farm vegetables and other food crops (Liu, 2020 May 12).

Private offices, hospitals, hotels and restaurants throughout Singapore have also adopted urban farming. For example, WOHA, a home-grown award-winning architecture practice known for working greenery into its buildings, started one such initiative in 2017. The firm used the rooftop of its office shophouse as a test bed for a 2,100 square foot organic urban farm with more than 100 species of edible plants, including kangkong, basil, pandan, dill and bittergourd, which are shared among the staff (Zakariah, 2017, June 3).

In another instance, the Changi General Hospital (a public hospital) started a rooftop hydroponic garden in 1998, which is able to absorb heat, making naturally ventilated wards cooler, while at the same time growing cherry tomatoes and herbs which are supplied to the hospital's patients (Greenroofs, n.d.). Two hotels, the Fairmont Singapore and Swissotel the Stamford, have recently started to harvest their own ingredients including herbs, edible greens and fish from the hotels' rooftops where aquaponic farms were recently installed (CNA, 2019). When fully operational, the farm will be able to produce about 1,200 kilograms of vegetables and 350 kilograms of fish monthly for the hotels' kitchens (CNA, 2019).

Sky Greens, one of the earliest high-tech urban farms set up in 2011 , is the world's first low carbon, hydraulic-driven vertical farm with over 1000 nine-meter tall towers of green plants (Skygreens, n.d.). This farm utilises A-Go-Gro technology, a hydroponic technique of revolving trays of vegetables around an aluminium tower six to nine metres tall and occupying 5.5 square metres of floor space (Singapore Magazine, 2015). This technology, jointly developed with the Agri-Food and Veterinary Authority (AVA) of Singapore, utilises only $40 \mathrm{~W}$ of electricity (equivalent to one light bulb) to power one 9-metre tall tower (Skygreens, n.d.). It harnesses natural sunlight, composts all organic waste on the farm (CNN Business, 2012), and is reported to yield five to ten times the yield of traditionally cultivated vegetables (Wang, 2012; Singapore Magazine, 2015). 
eTropic 19.2 (2020) Special Issue: Sustainable Tropical Urbanism

For its innovative design, Sky Greens Solutions (the company that owns Sky Greens) won the most prestigious biennial INDEX Award in 2015, the biggest design award in the world commonly referred to as the 'Nobel Prize' of design (Lim, 2015, August 29). Discussions regarding future expansions have commenced, with plans for parts of China, including Tianjin, Beijing, Fujian, and Xian as well as in New York, Puerto Rico, and the Middle East (Khoo, 2020).

\section{Public Policy and Urban Farming in Singapore}

As stated earlier in this paper, the Environment and Water Resources Minister in March 2019 announced the ambitious " 30 by 30" goal to locally produce 30 percent of Singapore's nutritional needs by the year 2030 (MEWR, 2019). The current COVID19 situation underscores the importance of local food production as part of Singapore's strategy to ensure food security. The Environment and Water Resources Ministry (MEWR) laid out four ways in which this can be achieved: using technology to grow more with less; unlocking physical spaces for farming; developing local talent; and getting consumers to support local growers (MEWR, 2019). To further strengthen its food security capabilities, the Singapore Food Agency (SFA) will launch plans for "30x30 Express" to accelerate local food production over the next six to 24 months (MEWR, 2020).

This announcement has led to several significant investments in indoor agricultural innovations and initiatives, including the setting up of accelerators, incubators, and providing investment opportunities and grants to start-ups working in the urban farming industry. More specifically, the Singapore Government has partnered/co-invested with seven accelerators to further invest in food and agriculture technology start-ups (Chong, 2019). These efforts have resulted in significant growth in vertical and rooftop farming, in particular, the successful Oh Chin Huat and Sky Greens operations, which have seen Singapore now producing $13 \%$ of the leafy greens consumed locally (Choo, 2019). The Sky Greens operations, as illustrated in the above section, epitomise successful collaboration between government and private sectors in bringing about the implementation of world-leading urban farming ventures in Singapore.

Government initiatives also came in the form of funding for R\&D investment in the agriculture and food production sectors. In line with the newly announced target to produce $30 \%$ of the nation's nutritional needs by 2030 , the Government will invest SGD \$144 million from its Research, Innovation and Enterprise 2020 (RIE2020) plan to intensify R\&D in the agri-food industry (Tang, 2019).

In this increasingly resource-constrained and consumer demand-driven world, research into ways in which to revolutionise how food is produced is increasingly 
eTropic 19.2 (2020) Special Issue: Sustainable Tropical Urbanism

undertaken by university and government collaborations. A case in point is the Singapore-MIT Alliance for Research and Technology (SMART) - a major research enterprise established by the Massachusetts Institute of Technology (MIT) in partnership with the National Research Foundation of Singapore (NRF) in 2007 (SMART, n.d.). For instance, the DISTAP (Disruptive and Sustainable Technologies for Agricultural Precision) research group at SMART is tapping into nanotechnology and microelectronics to create and produce high-value food components at increased volume and to apply these technologies to improve urban farming (SMART, n.d.).

To train more urban farmers, institutes of higher learning such as Temasek Polytechnic have launched various initiatives, including the Aquaculture Innovation Centre (AIC) in June 2019. The AIC is the first Centre of Innovation (COI) funded by Enterprise Singapore (a statutory board under the Ministry of Trade and Industry in Singapore) that adopts an inclusive and collaborative approach involving a consortium of 9 research institutes, agencies, universities and polytechnics in Singapore (Temasek Polytechnic, 2019). The AIC operates through co-operating and co-sharing of expertise, facilities, intellectual property and resources among the AIC consortium members to work towards serving the needs of the local aquaculture enterprises for improving farm productivity (Temasek Polytechnic, 2019).

\section{Challenges of Urban Farming in Singapore}

While urban farming has taken great strides in Singapore since its introduction in early 2010, there exist several challenges which could hinder its success. In a densely populated city like Singapore land scarcity remains a challenge exacerbated by a complex and restrictive regulatory legislative framework related to land use (Low, 2019). For example, land dedicated to farming is extremely limited, while land for community purposes does not allow farming (Low, 2019).

Building human capacity is another challenge that relates to many cities where most farm employees have been brought up as urban dwellers (Low, 2019). Many lack the experience and training to manage urban farms. Skilled labour to service these farms is also of concern, for although the vertical-farming system is automated, the harvesting and packing of vegetables is carried out manually by foreign workers. The issue of creating low-paying unskilled jobs remains a concern (Khoo, 2020). There is also a general lack of awareness for acting upon more sustainable consumption patterns in Singapore, thereby hindering further progress and advancement of vertical farm production. Moreover, questions remain as to how many consumers will be willing to pay for the higher-perceived quality of vertically farmed vegetables over traditionally farmed ones (Khoo, 2020). 
The centralised and intensive nature of urban farming operations suggest a higher vulnerability to disease and agro-terrorism (Khoo, 2020). Pests, viruses, bacterial, and fungal infestations can spread more rapidly in vertical farms where trays of vegetables are closely packed. If vertical farms were fully automated and computerised, there is a possibility that hackers can sabotage the facilities by breaking into their computer systems (Khoo, 2020). This is a potential threat that all highly automated operations need to overcome.

\section{Implications and Conclusion}

Singapore's technological industry capabilities along with effective policy support from the government to achieve food security has enabled the country to be a pioneer in the agri-food technology sector in Asia (Low, 2019). The collaboration between government, commercial firms and research institutions, has gathered momentum through the " 30 by 30 " goal, which seeks to produce $30 \%$ of its nutritional needs locally by 2030 .

The success of Sky Green's vertical farming lies in its value proposition as a scalable, cheap, low-carbon footprint vertical-farming system that requires minuscule quantities of electricity, water, and manpower for land-scarce urban cities (Khoo, 2020). Future vertical farms could be located on rooftops, barren land and run-down field sites (such as warehouses), thereby revitalising neglected city areas to yield economic and social benefits, as well as promote employment and well-being. The potential of urban farming for urban regeneration looks promising (Khoo, 2020).

The recognition of these forms of innovative farming (shown through the winning of the INDEX award), together with the potential for future expansion, indicates that vertical farming could become a powerful solution for sustainable agriculture in Singapore, a point further illustrated by support from the country's various stakeholders such as the government, research institutions, various industries, schools, and universities. Despite these opportunities, it is important to note that vertical farming initiatives such as the A-Go-Gro system used by Sky Greens, while successful in Singapore, might not be suitable for countries with seasonal changes as the system is better suited to tropical countries that receive an abundance of sunlight and water all year round.

Singapore's first forays into urban farming started with community gardens, then citizen farms, and rooftop farming, before finally venturing into large scale commercial production. Its successes reflect support from the government and collaboration between the private and public sectors. Overall, such developments may provide a good guide for other cities aspiring to grow their vertical farming capabilities. 
eTropic 19.2 (2020) Special Issue: Sustainable Tropical Urbanism

In the case of Singapore, the proactive participation and support from the government inspires and strengthens firms as they actively surmount some of the challenges urban farming presents. Singapore's desire to cluster businesses and universities with R\&D expertise to work together with urban and vertical farms will help to overcome some of the challenges that these industries face (Low, 2018, June 20). The future of the industry looks bright with the " 30 by 30 " goal very much achievable. Today's situation is by no means a fortuitous accident. It represents the kind of strategic planning that has allowed vertical farming to succeed in Singapore. 
eTropic 19.2 (2020) Special Issue: Sustainable Tropical Urbanism

\section{References}

Abel, C. (2010). The vertical garden city: towards a new urban topology. The Council on Tall Buildings and Urban Habitat Journal. 2, 20-30. https://global.ctbuh.org

Al-Chalabi, M. (2015). Vertical farming: Skyscraper sustainability? Sustainable Cities and Society, 18, 74-77. https://doi.org/10.1016/j.scs.2015.06.003

Armstrong, D. (2000). A survey of community gardens in upstate New York: Implications for health promotion and community development. Health and Place, 6(4), 319-327. https://doi.org/10.1016/S1353-8292(00)00013-7

Astee, L.Y., \& Kishnani, N. T. (2010). Building integrated agriculture: utilising rooftops for sustainable food crop cultivation in Singapore. Journal of Green Building, 5(2), 105113. https://doi.org/10.3992/jgb.5.2.105

Badami, M.G., \& Ramankutty, N. (2015). Urban agriculture and food security: A critique based on an assessment of urban land constraints. Global Food Security, 4, 8-15. https://doi.org/10.1016/j.gfs.2014.10.003

Banerjee, C. \& Adenaeuer, L. (2014). Up, up and away! The economics of vertical farming. Journal of Agricultural Studies 2(1), 40-60. https://doi.org/10.5296/jas.v2i1.4526

Benis, K \& Ferrao, P. (2018). Commercial farming within the urban built environment taking stock of an evolving field in northern countries. Global Food Security. 17, 3037. https://doi.org/10.1016/j.gfs.2018.03.005

Benis, K., Turan, I., Reinhart, C. \& Ferrão, P. (2018). Putting rooftops to use-A Cost-Benefit Analysis of food production vs. energy generation under Mediterranean climates. Cities, 78, 166-179. https://doi.org/10.1016/j.cities.2018.02.011

Benke, K.K. \& Tomkins, B. (2017). Future food-production systems: Vertical farming and controlled-environment agriculture. Sustainability: Science, Practice, and Policy 13(1),13-26. https://doi.org/10.1080/15487733.2017.1394054

Boh, S. (2017, November 17). A vegetable, fish farming system that is truly green. The Straits Times. https://www.straitstimes.com/singapore/a-vegetable-fish-farmingsystem-that-is-truly-green.

Bohn, K., \& Viljoen, A. (2011). The edible city: Envisioning the continuous productive urban landscape (CPUL). Field Journal 4(1), 149-161.

https://research.brighton.ac.uk/en/publications/the-edible-city-envisioning-thecontinuous-productive-urban-lands

Boisvert, W. (2013). An environmentalist on the lie of locavorism. The New York Observer. http://observer.com/2013/04/the-lie-of-locavorism/

Chen, Y., \& Wong, N.H. (2005). Study of green areas and urban heat island in a tropical city. Habitat International, 29(3), 547-558. https://doi.org/10.1016/j.habitatint.2004.04.008

Chong, C. (2019, January 21). Keep calm and carrot on - how agritech could transform farming in Singapore. The Business Times. https://www.enterprisesg.gov.sg/mediacentre/news/2019/january/keep-calm-and-carrot-on---how-agritech-could-transformfarming-in-singapore

Choo, C. (2019, Febraury 24). Singapore's farming revival: 'Tech is the only way to go'. Today Online. Singapore, Mediacorp. https://www.todayonline.com/singapore/superfish-speedy-rice-singapores-farming-revival

CNA (Channel NewsAsia) (2019, November 17). Aquaponics farming: How two hotels are looking to boost their sustainable practices. https://www.channelnewsasia.com/news/singapore/aquaponics-rooftop-farmfairmont-swissotel-stamford-hotels-12082350

CNN Business (2012, Dec 10). Future Cities - Singapore: Urban farming looking up in Singapore. https://edition.cnn.com/2012/12/09/business/eco-singapore-vertical-farm/ 
eTropic 19.2 (2020) Special Issue: Sustainable Tropical Urbanism

Cohen, A., Malone, S., Morris, Z., Weissburg, M. \& Bras, B. (2018). Combined Fish and Lettuce Cultivation: An Aquaponics Life Cycle Assessment. Procedia CIRP, 69, $551-$ 556. https://doi.org/10.1016/j.procir.2017.11.029

Despommier, D. (2010). The vertical farm: feeding the world in the 21st century. Macmillan.

Despommier, D. (2011). The vertical farm: controlled environment agriculture carried out in tall buildings would create greater food safety and security for large urban populations. Journal of Consumer Protection and Food Safety, 6, 233-236. https://doi.org/10.1007/s00003-010-0654-3

Despommier, D. (2013). Farming up the city: the rise of urban vertical farms. Trends Biotechnology, 31, 388-389. https://doi.org/10.1016/j.tibtech.2013.03.008

Diehl, J.A., Sia, C.S. \& Chandra, A.J. (2019). Cities linked through trans-boundaries: The case of Singapore as an agri-pelago. In E. Gottero (Eds), Agrourbanism: Tools for governance and planning of agrarian landscape, pp. 45-60. Springer. https://doi.org/10.1007/978-3-319-95576-6 4

Draaisma, R.B., Wijels, R. H., Slegers, P., Brentner, L.B., Roy, A. \& Barbosa, M.J. (2013). Food commodities from microalgae. Current Opinions in Biotechnology, 24, 169-177. https://doi.org/10.1016/j.copbio.2012.09.012

Ellingsen, E., \& Despommier, D. (2008). The vertical farm - The origin of a 21st century. The Council on Tall Buildings and Urban Habitat Journal, 3, 26-34.

https://global.ctbuh.org/resources/papers/download/449-the-vertical-farm-the-originof-a-21st-century-architectural-typology.pdf

Ellis, J. (2012). Agricultural transparency: Reconnecting urban centres with food production. (Unpublished Master's Thesis). Dalhousie University, Halifax, Nova Scotia.

Fatemeh, K., Mohd, T. O., Akbari, J.R., \& Ezaz, F. (2018). Opportunities and challenges in sustainability of vertical farming: A Review. Journal of Landscape Ecology, 11(1), 3560. https://doi.org/10.1515/ilecol-2017-0016

Food and Agriculture Organization (FAO, 2014). Urban agriculture. http://www.fao.org/3/ai3696e.pdf

Food and Agriculture Organization (FAO, 2017). The future of food and agriculture: Trends and Challenges. Rome: Food and Agriculture Organisation of United Nations. http://www.fao.org/3/a-i6583e.pdf

Forchino, A.A., Gennotte, V., Maiolo, S., Brigolin, D., Mélard, C. \& Pastres, R. (2018). Ecodesigning aquaponics: A case study of an experimental production system in Belgium. Procedia CIRP, 69, 546-550. https://doi.org/10.1016/i.procir.2017.11.064

Fortado, L. \& Terazono, E. (2019, July 9). AeroFarms raises $\$ 100 m$ as investors rush to indoor farms. Financial Times. https://www.ft.com/content/cac48190-9d8a-11e99c06-a4640c9feebb

Germer, J., Sauerborn, J., Asch, F., de Boer, J., Schreiber, J., Weber, G., \& Müller, J. (2011). Skyfarming an ecological innovation to enhance global food security. Journal of Consumer Protection and Food Safety, 6(2), 237-251. https://doi.org/10.1007/s00003-011-0691-6

Greenroofs (n.d.). Changi General Hospital. Retrieved July 9, 2020 from https://www.greenroofs.com/projects/changi-general-hospital/

Grewal, S.S., \& Grewal, P.S. (2012). Can cities become self-reliant in food? Cities, 29(1), 111. https://doi.org/10.1016/j.cities.2011.06.003

Haberman, D., Gillies, L., Canter, A., Rinner, V., Pancrazi, L., \& Martellozzo, F. (2014). The potential of urban agriculture in Montréal: A quantitative assessment. ISPRS

International Journal of Geo-information, 3(3), 1101-1117. https://doi.org/10.3390/ijgi3031101

Hale, J., Knapp, C., Bardwell, L., Buchenau, M., Marshall, J., \& Sancar, F. (2011). Connecting food environments and health through the relational nature of aesthetics: 
Gaining insight through the community gardening experience. Social Science and Medicine, 72(11), 1853-1863. https://doi.org/10.1016/j.socscimed.2011.03.044

Hinrichs, C. (2000). Embeddedness and local food systems: notes on two types of direct agricultural market. Journal of Rural Studies. 16, 295-303. https://doi.org/10.1016/S0743-0167(99)00063-7

Johnson, M.S., Lathuillière, M.J., Tooke, T.R., \& Coops, N.C. (2015). Attenuation of urban agricultural production potential and crop water footprint due to shading from buildings and trees. Environmental Research Letters, 10(6), 1-11. https://doi.org/10.1088/1748-9326/10/6/064007

Kalantari, F., Tahir, O.M., Joni, R.A., \& Fatemi, E. (2018). Opportunities and challenges in sustainability of vertical farming: A review. Journal of Landscape Ecology, 11(1), 3560. https://doi.org/10.1515/ilecol-2017-0016

Kalantari, F., Tahir, O.M., Lahijani, A.M., \& Kalantari, S. (2017). A review of vertical farming technology: A guide for implementation of building integrated agriculture in cities. Advanced Engineering Forum, 76-91. https://doi.org/10.4028/www.scientific.net/AEF.24.76

Khoo, H. M. (2020). Sky urban solutions: Vertical farming - an urban agriculture solution. Nanyang Technopreneurship Case Centre.

http://www.ntc.ntu.edu.sg/ntcc/Documents/Full\%20Version/20.\%20SKY\%20URBAN \%20SOLUTIONS\%20-\%20VERTICAL\%20FARMING\%20\%20AN\%20URBAN\%20AGRICULTURE\%20SOLUTION.pdf

Kuah, A. T. H. (2018). Tropical Urbanisation and the Life of Public Housing in Singapore. [Special issue Living Cities: Tropical Imaginaries] eTropic: Electronic Journal of Studies in the Tropics, 17(1), 41-59 https://doi.org/10.25120/etropic.17.1.2018.3641

Leyl, S. (2014, February 27). How do Singapore's poor families get by? British Broadcasting Corporation. London, United Kingdom. https://www.bbc.com/news/world-asia26349689

Lim, J. (2019, August 29). Vertical farming invention wins global award. The Straits Times. https://www.straitstimes.com/singapore/vertical-farming-invention-wins-global-award

Liu, V. (2019, December 10). Singapore tops food security index for 2nd straight year. The Straits Times. https://www.straitstimes.com/singapore/singapore-tops-food-securityindex-for-2nd-straight-year

Liu, V. (2020, April 8). Coronavirus: New \$30m grant launched to speed up local production of eggs, vegetables and fish. The Straits Times.

https://www.straitstimes.com/singapore/coronavirus-new-30m-grant-launched-tospeed-up-local-production-of-eggs-vegetables-and

Liu, V. (2020, May 12). Nine multi-storey carpark rooftops in Singapore to be converted to urban farms. The Straits Times. https://www.straitstimes.com/singapore/nine-multistorey-carpark-rooftops-in-singapore-to-be-converted-to-urban-farms

Love, D.C., Fry, J. P., Li, X., Hill, E. S., Genello, L., Semmens, K. \& Thompson, R. E. (2015). Commercial aquaponics production and profitability: Findings from an international survey. Aquaculture, 435, 67-74. https://doi.org/10.1016/j.aquaculture.2014.09.023

Low, B. (2019). Building sustainable urban farms with government support in Singapore. Field Actions Science Reports, Special Issue 20, 98-103. http://journals.openedition.org/factsreports/5824

Low, D.W. (2018, June 20). Strawberries grown in Singapore vertical farm make debut. The Straits Times. https://www.straitstimes.com/singapore/strawberries-grown-insingapore-vertical-farm-make-debut.

Mansfield, B., \& Mendes, W. (2013). Municipal food strategies and integrated approaches to urban agriculture: Exploring three cases from the global north. International Planning Studies, 18(1), 37-60. https://doi.org/10.1080/13563475.2013.750942 
eTropic 19.2 (2020) Special Issue: Sustainable Tropical Urbanism

Meharg, A. (2016, 17 Mar). City farming needs monitoring. Nature, 531, (7594). S60. https://doi.org/10.1038/531S60a

MEWR (Ministry of the Environment and Water Resources) (2019, Mar 7). A MEWR trilogy: Our food and environmental stories develop from our water story. Speech by Mr Masagos Zulkifli, Minister for the Environment and Water Resources, at the Committee of Supply Debate 2019, on March 7, 2019. https://www.mewr.gov.sg/.../speech-by-mr-masagos-zulkifli--minister-for-the environment-and-water-resources--at-the-committee-of-supply-debate-201.

MEWR (Ministry of the Environment and Water Resources) (2020, April 8). 30x30 Express: Ramping Up Local Production to Enhance Singapore's Food Security. Press Release. https://www.mewr.gov.sg/news/30x30-express--ramping-up-localproduction-to-enhance-Singapores-food-security

Montero, J.I., Baeza, E., Heuvelink, E., Rieradevall, J., Muñoz, P., Ercilla, M. \& Stanghellini, C. (2017). Productivity of a building-integrated roof top greenhouse in a Mediterranean climate. Agricultural Systems, 158, 14-22. https://doi.org/10.1016/j.agsy.2017.08.002

Morgan, K. (2015). Nourishing the city: The rise of the urban food question in the Global North. Urban Studies, 52(8), 1379-1394. https://doi.org/10.1177/0042098014534902

Oonincx, D. G. A. B., van Itterbeeck, J., Heetkamp, M. J. W., van den Brand, H., van Loon, J. J. A. \& van Huis, A. (2010). An exploration on greenhouse gas and ammonia production by insect species suitable for animal or human consumption. PLOS ONE, 5, e14445. https://doi.org/10.1371/journal.pone.0014445

Opitz, I., Berges, R., Piorr, A., \& Krikser, T. (2016). Contributing to food security in urban areas: differences between urban agriculture and peri-urban agriculture in the Global North. Agriculture and Human Values, 33(2), 341-358. https://doi.org/10.1007/s10460-015-9610-2

Perez, V.M. (2014). Study of the Sustainability issue of food production using vertical farm Mlmethods in an urban environment within the state of Indiana. Thesis. Purdue University.

https://docs.lib.purdue.edu/cgi/viewcontent.cgi?referer=https://www.google.com/\&http sredir $=1 \&$ article $=1242 \&$ context $=$ open access theses

Pfeiffer, A., Silva, E. \& Colquhoun, J. (2013). Innovation in urban agricultural practices: Responding to diverse production environments. Renewable Agriculture and Food Systems, 30(1), 79-91. https://doi.org/10.1017/S1742170513000537

Platt, P. (2007). Vertical Farming: An Interview with Dickson Despommier. Gastronomica, 7(3), 80-87. https://doi.org/10.1525/gfc.2007.7.3.80

Poulsen, M.N., McNab, P.R., Clayton, M.L. \& Neff, R.A. (2015). A systematic review of urban agriculture and food security impacts in low-income countries. Food Policy, 55, 131146. https://doi.org/10.1016/j.foodpol.2015.07.002

Sanjuan-Delmás, D., Llorach-Massana, P., Nadal, A., Ercilla-Montserrat, M., Muñoz, P., Montero, J. I., Josa, A., Gabarrell, X. \& Rieradevall, J. (2018). Environmental assessment of an integrated rooftop greenhouse for food production in cities. Journal of Cleaner Production, 177, 326-337. https://doi.org/10.1016/j.jclepro.2017.12.147

Sanye-Mengual, E., Anguclovski, I., Oliver-Sola, J., Montero, J.J. \& Rieradevali, J. (2016). Resolving differing stakeholder perceptions of urban rooftop farming in Mediterranean cities: promoting food production as a driver for innovative forms of urban agriculture. Agriculture and Human Values, 33, 101-120. https://doi.org/10.1007/s10460-015-9594-y

Segal, A. (2010). Food desserts: A global crisis in New York City. Causes, Impacts and Solutions. The Journal of Sustainable Development, 3(1), 197-214. https://www.jstor.org/stable/26167795 
eTropic 19.2 (2020) Special Issue: Sustainable Tropical Urbanism

Shamshiri, R.R., Kalantari, F., Ting, K.C., Thorp, K.R., Hameed, I. A., Weltzien, C., Ahmad, D. \& Shad, Z. M. (2018). Advances in greenhouse automation and controlled environment agriculture: A transition to plant factories and urban agriculture. International Journal of Agricultural and Biological Engineering, 11(1): 1-22. https://doi.org/10.25165/j.ijabe.20181101.3210

Siegner, A., Sowerwine, J. \& Acey, C. (2018). Does urban agriculture improve food security? Examining the nexus of food access and distribution of urban produced foods in the United States: A systematic review. Sustainability 10(9), 2988. https://doi.org/10.3390/su10092988

Singapore Food Agency (SFA, 2020). Singapore Food Story (SFS) R\&D program: Strategic grant call (Theme 1: Sustainable urban food production). https://www.sfa.gov.sg/docs/default-source/food-farming/sfs-rd-grant-call-theme1informationsheet.pdf

Singapore Magazine. (2015, July - September). Farming in the sky. http://singaporemagazine.sif.org.sg/farming-in-the-sky

Singapore National Parks (n.d.). Community in Blooms Initiatives. Retrieved from https://www.nparks.gov.sg/gardening/community-in-bloom-initiative.

Sivaman,i S., Bae, N.J., Shin, C.S., Park, J.W., Cho, Y.Y. (2014). An OWL-based ontology model for intelligent service in vertical farm. In: Jeong, H., Obaidat, M., Yen, N. \& Park, J. (eds) Advances in computer science and its applications. Lecture Notes in Electrical Engineering, 279, 327 - 332, Springer, Berlin, Heidelberg. https://doi.org/10.1007/978-3-642-41674-3 47

Skygreens (n.d.). About Sky Greens. Retrieved July 15, 2020 from https://www.skygreens.com/about-skygreens/.

SMART (Singapore-MIT Alliance for Research and Technology). (n.d.). Research: Disruptive \& sustainable technologies for agricultural precision. Retrieved from https://smart.mit.edu/research/distap/about-distap

Smit, J. \& Nasr, J. (1992). Urban agriculture for sustainable cities: Using wastes and idle land and water bodies as resources. Environment and Urbanisation, 4(2), 141-152. https://doi.org/10.1177/095624789200400214

Smit, J., Nasr, J. \& Ratta, A. (2001). Urban agriculture: Food, jobs and sustainable cities. 2001 edition, published with permission from the United Nations Development Program, Washington, D.C. USA: The Urban Agriculture Network, Inc. http://jacsmit.com/book/Chap02.pdf

Specht, K., Siebert, R., Hartmann, I., Freisinger, U.B., Sawicka, M., Werner, A., \& Dierich, A. (2014). Urban agriculture of the future: An overview of sustainability aspects of food production in and on buildings. Agriculture and Human Values, 31(1), 33-51. https://doi.org/10.1007/s10460-013-9448-4

Specht, K., Siebert, R. \& Thomaier, S. (2016). Perception and acceptance of agricultural production in and on urban buildings (ZFarming): A qualitative study from Berlin, Germany. Agricultural Human Values, 33, 753-769. https://doi.org/10.1007/s10460015-9658-Z

Specht, K., Zoll, F., Schümann, H., Bela, J., Kachel, J. \& Robischon, M. (2019). How will we eat and produce in the cities of the future? From edible insects to vertical farming-A study on the perception and acceptability of new approaches. Sustainability, 11, 4315. https://doi.org/10.3390/su11164315

Subramaniam, R., \& Lee, S. K. (2012). Aeroponics: Experiences from Singapore on a green technology for urban farming. In D. R. Gallagher (Ed.), Environmental leadership: A reference handbook (pp. 653-662). Sage. https://doi.org/10.4135/9781452218601.n69

Surls, R., Feenstra, G., Golden, S., Galt, R., Hardesty, S., \& Napawan, C., (2015). Gearing up to support urban farming in California: Preliminary results of a needs assessment. 
eTropic 19.2 (2020) Special Issue: Sustainable Tropical Urbanism

Renewable Agriculture and Food Systems, 30(1), 33-42.

https://doi.org/10.1017/S1742170514000052

Tang, S. K. (2019, March 29). Tech for urban farming among R\&D focus as Singapore looks to beef up food security. CNA (Channel News Asia) International Edition. Retrieved from https://www.channelnewsasia.com/news/business/singapore-food-security-techresearch-development-11385052

Taylor, J.R., \& Lovell, S.T. (2012). Mapping public and private spaces of urban agriculture in Chicago through the analysis of high-resolution aerial images in Google Earth.

Landscape and Urban Planning, 108(1), 57-70. https://doi.org/10.1016/j.landurbplan.2012.08.001

Teh, C. (2019, March 5). Fresh veggies, all from rooftop farm at HDB carpark. The Straits Times. https://www.straitstimes.com/singapore/environment/fresh-veggies-all-fromrooftop-farm-at-hdb-carpark

Temasek Polytechnic (2019). Aquaculture Innovation Centre Overview. https://www.tp.edu.sg/research-and-industry/centres-of-excellence/aquacultureinnovation-centre-aic.html

The Economist (2010, December 11). Vertical farming: Does it really stack up? The Economist.https://www.economist.com/technology-quarterly/2010/12/11/does-itreally-stack-up

The Economist EIU (2019). The Global Food Security Index. https://foodsecurityindex.eiu.com/Country

The Smart Local (2019, August 9). 9 Urban farms in Singapore for locally-grown vegetables of high quality. https://thesmartlocal.com/read/urban-farms/

Toledano, B. (2019, November 4). The second generation of vertical farming is approaching. Here is why it is important. https://agfundernews.com/the-second-generation-ofvertical-farming-is-approaching-heres-why-its-important.html

UN-Habitat (2014). Integrating urban and peri-urban agriculture into city-level climate change strategies, Cities and Climate Change Initiative, UN-Habitat.

United Nations. (2018, May 16). 2018 Revision of World Urbanization Prospects. Retrieved from https://www.un.org/development/desa/publications/2018-revision-of-worldurbanization-prospects.html

Van der Schans, J.W \& Wiskerke, J.S.C. (2012). Urban agriculture in developed economies. In A. Viljoen and J. S.C Wiskerke (Eds). Sustainable food planning: evolving theory and practice. Wageningen Academic Publishers pp. 245-258. https://doi.org/10.3920/978-90-8686-187-3 21

Voss, P. M. (2013). Vertical Farming: An agricultural revolution on the rise. Halmstad, 1-21. https://www.diva-portal.org/smash/record.jsf?pid=diva2\%3A628988\&dswid=8657

Wang, B. (2012, August 11). 4 Story tall vertical farm that is up to ten times more productive than regular farms. NextBigFuture. Retrieved from https://www.nextbigfuture.com/2012/11/4-story-tall-vertical-farm-that-is-up.html

Yuan, C., Shan, R., Adelia, A.S., Tablada, A. Lau, S. K. and Lau, S. S. (2019). Effects of vertical farming on natural ventilation of residential buildings. Energy and Buildings. 185, 316-325. https://doi.org/10.1016/j.enbuild.2018.12.028

Yuttitham, M. (2019). Comparison of Carbon Footprint of Organic and Conventional Farming of Chinese Kale. Environment and Natural Resources Journal, 17(1), 78 - 92. https://doi.org/10.32526/ennrj.17.1.2019.08

Zachariah, N.A. (2017, June 3). Urban farming in Singapore has moved into a new, hightech phase. The Straits Times. https://www.straitstimes.com/lifestyle/homedesign/fresh-ideas-for-city-farms 
eTropic 19.2 (2020) Special Issue: Sustainable Tropical Urbanism

Dr Jacob Wood is the Associate Dean of Research (ADR) for the College of Business, Law and Governance, James Cook University (JCU), Australia and the ADR of Business/IT/Science at JCU Singapore. He is also the Director of the Centre for International Trade and Business in Asia (CITBA) and an Associate Professor of Business at James Cook University Singapore. In addition to this, he is a Visiting Professor of International Trade at Chungnam National University, Daejeon, South Korea. His research interests are risk management, the use of non-tariff barriers, the WTO Dispute Settlement Mechanism and sustainable transportation development. Dr Wood has published in the Journal of World Trade, the Singapore Economic Review, International Journal of Disaster Risk Management, Risk Management, Technology Analysis and Strategic Management, Sustainability, Scientometrics, Economies, and the Journal of Asia-Pacific Economic Literature among others.

Dr Caroline Wong is the Associate Dean of Learning and Teaching (ADLT) and a Senior Lecturer at James Cook University Singapore. Her research in knowledge management takes on a multidisciplinary approach that extends into knowledgebased cities, smart cities, creative cities, and creative industries with special focus on Singapore. She was a founding member of the International Scientific Committee of the Knowledge Cities World Summit in Monterrey (Mexico) in 2007 and a member of the International Advisory Board on knowledge-based cities between the years 20072009. She has published in the Journal of Competence-Based Strategic Management, International Journal of Knowledge, Culture and Change Management, Journal of Knowledge Management and the Journal of University Teaching and Learning Practice. Her academic research extends into the scholarship of teaching and learning in higher education with focus on experiential learning, intervention programs, teamwork and entrepreneurship.

Swathi Paturi is a CITBA Research Fellow at James Cook University Singapore. She has previously pursued Bachelor's courses in Mechanical Engineering at Waikato University, New Zealand and the University of Cincinnati, USA, where she served as the International Ambassador from 2015-2016. Her research interests include food sustainability, agribusiness, agriculture technology and sustainability. She has been published in eTropic: electronic journal of studies in the tropics. 